\title{
Changes in Composition and Function of Human Intestinal Microbiota Exposed to Chlorpyrifos in Oil as Assessed by the SHIME ${ }^{\circledR}$ Model
}

\author{
Julie Reygner ${ }^{1,2,+}$, Claire Joly Condette ${ }^{1,3, \dagger}$, Aurélia Bruneau ${ }^{4,5}$, Stéphane Delanaud ${ }^{1}$, \\ Larbi Rhazi $^{2}$, Flore Depeint ${ }^{2}$, Latifa Abdennebi-Najar ${ }^{2}$, Veronique Bach ${ }^{1}$, Camille Mayeur ${ }^{5,6, \ddagger}$ \\ and Hafida Khorsi-Cauet ${ }^{1, *, \neq}$ \\ 1 Laboratoire Périnatalité et Risques Toxiques (PERITOX), UMR-I01 INERIS, UPJV-CURS CHU Sud, \\ Avenue Laennec, F-80054 Amiens CEDEX 1, France; julie.reygner@u-picardie.fr (J.R.); \\ claire.joly@u-picardie.fr (C.J.C.); stephane.delanaud@u-picardie.fr (S.D.); veronique.bach@u-picardie.fr (V.B.) \\ 2 UP-EGEAL 2012.10.101, Institut Polytechnique LaSalle Beauvais, 19 Rue Pierre Waguet, \\ F-60026 Beauvais CEDEX, France; larbi.rhazi@lasalle-beauvais.fr (L.R.); \\ flore.depeint@lasalle-beauvais.fr (F.D.); latifa.najar@lasalle-beauvais.fr (L.A.-N.) \\ 3 Laboratoire Lymphocyte Normal, Pathologique et Cancer (LNPC), EA4666, UPJV-CURS CHU Sud, \\ Avenue Laennec, F-80054 Amiens CEDEX 1, France \\ 4 INRA, UMR1319 MICALIS, AMIPEM, F-78350 Jouy-en-Josas, France; aurelia.bruneau@inra.fr \\ 5 AgroParisTech, UMR1319 MICALIS, F-78350 Jouy-en-Josas, France; camille.mayeur@inra.fr \\ 6 Commensal and Probiotics-Host Interactions Laboratory, INRA, UMR1319 MICALIS, \\ F-78350 Jouy-en-Josas, France \\ * Correspondence: hafida.khorsi@u-picardie.fr; Tel.: +33-322-827-898 \\ + These two authors contributed equally to the work. \\ $\ddagger$ These two co-senior authors contributed equally to the work.
}

Academic Editor: Ricardo Bello-Mendoza

Received: 8 July 2016; Accepted: 27 October 2016; Published: 4 November 2016

\begin{abstract}
The presence of pesticide residues in food is a public health problem. Exposure to these substances in daily life could have serious effects on the intestine-the first organ to come into contact with food contaminants. The present study investigated the impact of a low dose (1 mg/day in oil) of the pesticide chlorpyrifos (CPF) on the community structure, diversity and metabolic response of the human gut microbiota using the SHIME ${ }^{\circledR}$ model (six reactors, representing the different parts of the gastrointestinal tract). The last three reactors (representing the colon) were inoculated with a mixture of feces from human adults. Three time points were studied: immediately before the first dose of $\mathrm{CPF}$, and then after 15 and 30 days of CPF-oil administration. By using conventional bacterial culture and molecular biology methods, we showed that CPF in oil can affect the gut microbiota. It had the greatest effects on counts of culturable bacteria (with an increase in Enterobacteria, Bacteroides spp. and clostridia counts, and a decrease in bifidobacterial counts) and fermentative activity, which were colon-segment-dependent. Our results suggest that: (i) CPF in oil treatment affects the gut microbiota (although there was some discordance between the culture-dependent and culture-independent analyses); (ii) the changes are "SHIME ${ }^{\circledR}$-compartment" specific; and (iii) the changes are associated with minor alterations in the production of short-chain fatty acids and lactate.
\end{abstract}

Keywords: pesticide; microbiota; human fecal ecosystem; diversity; functional activity; SHIME ${ }^{\circledR}$ model

\section{Introduction}

In recent years, the intensive use of pesticides has become a worldwide public health concern. One of the most commonly used pesticides in agricultural and residential applications is chlorpyrifos 
$(\mathrm{CPF})$, an inexpensive organophosphate compound that kills a broad spectrum of insects. Despite its now limited use in the USA and Europe, CPF is still widely used in other parts of the world, including Asia [1]. The widespread use of CPF leads to exposure through dermal, respiratory and oral routes. Residual CPF in food (especially in fruits and vegetables) at a level below that required for acute toxicity constitutes the main pathway for exposure [2,3]. CPF is a powerful, acutely neurotoxic compound that acts (through a CPF-oxon metabolite) by inhibiting acetylcholinesterase (AChE) in the nerve synapse. This results in functional changes in the organism's tissues [4]. The clinical signs of acute pesticide poisoning in humans include tremors, eye tearing, headaches, nausea, behavioral disorders, stomach cramps, diarrhea and potentially life-threatening respiratory failure [5]. Nonetheless, several animal studies have shown that CPF exposure at levels below the threshold for systemic toxicity (inhibition of brain AChE) exerts disruptive effects on biological processes such as the cell cycle, apoptosis and DNA synthesis through non-cholinergic mechanisms [6,7]. Surprisingly, there are few animal studies of CPF's effects on the gastrointestinal tract-the first organ to come into contact with food contaminants. In 2003, Cook et al. used a rat perfusion model to show that $99 \%$ of orally administered CPF is absorbed by the small intestine [8]. In 2012, another study indicated that CPF is biotransformed by cytochrome P450 in the upper part of the small intestine [9]. Lastly, Joly Condette et al.'s rat study showed for the first time that exposure to a low dose of pesticide causes morphological changes in the intestinal epithelium, increases intestinal permeability and bacterial translocation, and is associated with an imbalance in the intestinal microbiota $[10,11]$.

The human gut is colonized by a broad variety of microorganisms, and disruption of the gut's bacterial profile has often been linked to pathologies such as inflammatory bowel disease [12], obesity and diabetes $[13,14]$. The gut microbiota is a complex, dynamic ecosystem. It is composed mainly of bacteria but also comprises Archaea and yeasts. The bacterial count rises from the proximal colon to the distal colon, and reaches values of $10^{11}$ to $10^{12} / \mathrm{g}$ in feces [15]. The great majority of these bacteria are anaerobes from three main phyla: Gram-negative Bacteroidetes, Gram-positive Firmicutes, and Actinobacteria [16]. Among the Firmicutes, the butyrate-producing bacteria found in human feces belong to Clostridium clusters IV (C. leptum) and XIVa (C. coccoides) [17,18]. Gram-positive bifidobacteria and lactic acid bacteria (LAB, such as Lactobacillus spp.) are minor bacterial groups in humans but have a major role in human health [19]. The most distinctive benefits of bifidobacteria are modulation of host defense responses and protection against infectious diseases [20,21]. Fukuda et al. have shown that production of acetate by Bifidobacteria protects against E. coli infection [22]. Indeed, the gut microbiota in general has an important role in an individual's health and well-being; it is involved in the host's physiology, the regulation of metabolism and the extraction of energy from ingested food [23]. Thus, bacteria possess an arsenal of genes (the microbiome) encoding enzymes involved in nutrient fermentation. Dietary fibers are fermented by intestinal bacteria into short-chain fatty acids (SCFAs, such as butyrate, acetate and propionate) that have local and/or systemic effects [18,24].

Given the gut microbiota's key role in host homeostasis, factors such as antibiotics [25,26], diet [27] and toxics (including pesticides) $[10,11,28,29]$ can influence the intestine microbiota composition. In rodent models, chronic exposure to pesticide-contaminated foods leads to gut microflora dysbiosis; more specifically, the abundance of Lactobacillaceae fell significantly during CPF exposure [11,29]. Only two in vitro studies of the effects of low-dose CPF (mimicking chronic exposure) on the intestine have been published. Firstly, Tirelli et al. showed that CPF increases membrane permeability in an enterocyte cell culture model [30]. Secondly, Joly et al. used the in vitro Simulator of the Human Intestinal Microbial Ecosystem $\left(\mathrm{SHIME}^{\circledR}\right.$ ) to show that CPF exposure was associated with an increase in the total cultured bacterial count (a pattern associated with dysbiosis) [28]. In fact, CPF exposure resulted in an increase in the cultured Enterococcus spp. and Bacteroides spp. counts and a decrease in the number of lactic acid bacteria (LAB, such as Lactobacillus spp. and the bifidobacteria). The SHIME ${ }^{\circledR}$ model is known to be a useful tool for studying: (i) interactions between microbiota; and (ii) the effects of prebiotics and other compounds on the microbial community's composition and metabolic activities [31,32]. The SHIME ${ }^{\circledR}$ has already been used to study the effect of prebiotics 
(such as fructooligosaccharide and inulin) on the fermentation pattern of the colon microbiota [33-35]. Microbiota interactions in this in vitro model have also been monitored, in order to investigate the relationship between the structure of gut microbial communities fed with different diets and their functional stability when challenged with antibiotics [32].

We used the SHIME ${ }^{\circledR}$ in vitro model and molecular biology techniques to study the direct effects of below-threshold doses of CPF ( $1 \mathrm{mg} /$ day, dissolved in rapeseed oil) on the composition, diversity and metabolic functions of the human fecal microbiota. Our data show that chronic CPF exposure ( $1 \mathrm{mg} /$ day in oil) caused slight, transient changes in bacterial counts and fermentative activity, and shifted the human gut microbiota's diversity profile.

\section{Materials and Methods}

\subsection{Chemicals}

Chlorpyrifos (O,O-diethyl, $O$-(3,5,6-trichloro-2-pyridyl)phosphorothioate, purity $99.8 \% \pm 0.1 \%$; LGC Standards, Molsheim, France) was dissolved in rapeseed oil (MP Biomedicals, Illkirch, France) and administered daily to the stomach compartment of the in vitro culture system at a dose of $1 \mathrm{mg} / 10 \mathrm{~mL}$ oil in a total feed volume of $200 \mathrm{~mL}$ (corresponding to the stomach compartment's volume).

\subsection{Description of the SHIME ${ }^{\circledR}$}

The SHIME ${ }^{\circledR}$ is a dynamic, in vitro model that represents the different parts of the adult human gastrointestinal tract [36]. It is formed by six double-jacketed reactors simulating the stomach, the duodenum/jejunum, the ileum/caecum and the three segments (ascending, transverse and descending) of the colon (Table 1). All reactors were continuously stirred, held at $37^{\circ} \mathrm{C}$ and kept under anaerobic conditions by flushing them with nitrogen for 15 min once a day. The last three reactors were maintained at physiological pH. Three times a day, $200 \mathrm{~mL}$ of SHIME ${ }^{\circledR}$ feed and $90 \mathrm{~mL}$ of pancreatic juice (as described by [36,37]) were added to the stomach and duodenum/jejunum reactors, respectively. The last three reactors were inoculated with a mixture of fecal microbiota from four healthy adult volunteers, none of whom had suffered from gastrointestinal diseases or had taken antibiotics in the previous six months. Details of the inoculum have been published elsewhere [28]. Here, we describe a single "before-after" study in a single SHIME ${ }^{\circledR}$. During the first two weeks of the experiment, control nutritional medium was added to the reactors; this enabled the bacterial community to adapt to the in vitro conditions and stabilize [38]. After this period, CPF $1 \mathrm{mg} / \mathrm{day}$ in oil was administered for 4 weeks. Samples were collected and analyzed at three time points: day D0 (after two weeks of microbiota stabilization and immediately before the first dose of CPF treatment) and after 15 (D15) and 30 (D30) days of treatment with CPF $1 \mathrm{mg} /$ day in oil.

Table 1. Set-up of the SHIME ${ }^{\circledR}$, with reactor volumes, residence times and $\mathrm{pH}$ values (based on [28]).

\begin{tabular}{cccc}
\hline Reactor & Volume $\mathbf{( m L )}$ & Residence Time (h) & pH \\
\hline R1: Stomach & 200 & 3 & 2 \\
R2: Duodenum/Jejunum & 300 & 3 & 7 \\
R3: Ileum/Caecum & 300 & 4 & 7 \\
R4: Ascending Colon & 1000 & 20 & $5.5-6.0$ \\
R5: Transverse Colon & 1600 & 32 & $6.0-6.4$ \\
R6: Descending Colon & 1200 & 24 & $6.4-6.8$ \\
\hline
\end{tabular}

\subsection{Plate Counts}

The bacterial groups in liquid samples from each colon reactor (R4-R6) were analyzed on D0, D15 and D30, using specific media (Table 2). Ten-fold serial dilutions were prepared in Ringer's solution (Oxoid, Basingstoke, UK). To provide technical replicates, two plates per dilution were inoculated with $0.1 \mathrm{~mL}$ of the two most appropriate sample dilutions. One plate was incubated at $37^{\circ} \mathrm{C}$ for 
$48 \mathrm{~h}$ (to determine the aerobe count) and the other was incubated at $37^{\circ} \mathrm{C}$ for 4 days in an anaerobic chamber (Bactron Anaerobic, Sheldon Manufacturing, Cornelius, OR, USA) to determine the anaerobe count. The "total bacteria" count corresponds to the sum of the $\log (\mathrm{CFU} / \mathrm{mL})$ of total aerobes and the $\log (\mathrm{CFU} / \mathrm{mL})$ of total anaerobes.

Table 2. Media and conditions used to determine counts of anaerobic and aerobic microbes.

\begin{tabular}{ccc}
\hline Bacterial Group & Medium & Condition \\
\hline Total Aerobes & Columbia Agar ${ }^{\text {a }}$ & Aerobic \\
Total Anaerobes & Blood Columbia Agar & Anaerobic \\
Bacteroides spp. & Schaedler Agar ${ }^{\text {a }}$ & Anaerobic \\
Clostridium spp. & Shahidi-Ferguson Perfringens a & Anaerobic \\
Enterobacteria & Bromocresol Purple a & Aerobic \\
Lactic Acid Bacteria & de Man Rogosa Sharpe & Aerobic \\
Bifidobacteria & Bereens & Anaerobic \\
\hline
\end{tabular}

${ }^{a}$ Oxoid, Dardilly, France; ${ }^{\mathrm{b}}$ Sigma-Aldrich, Saint Quentin Fallavier, France.

\subsection{SCFA Assays}

$\mathrm{SHIME}^{\circledR}$ liquid samples from each colon reactor were collected and then frozen at $-20{ }^{\circ} \mathrm{C}$. Acetate, propionate, butyrate, valerate, caproate and branched SCFA concentrations were analyzed using gas-liquid chromatography after the aqueous extraction of acidified samples (Nelson 1020, Perkin-Elmer, St Quentin en Yvelines, France), as described by [39]. Gas chromatography was performed using a polyethylene glycol Nucol column (Supelco, Saint-Quentin Fallavier, France) under isothermal conditions in an oven at $100^{\circ} \mathrm{C}$, with a hydrogen flow rate of $10 \mathrm{~mL} / \mathrm{min}$, an on-column injector operating at $200{ }^{\circ} \mathrm{C}$ and an flame ionization detector operating at $240{ }^{\circ} \mathrm{C}$. SCFA concentrations were expressed in $\mathrm{mmol} / \mathrm{L}$.

\subsection{L- and D-Lactate Assay}

L- and D-lactate levels were measured as described previously [40]. Briefly, SHIME ${ }^{\circledR}$ samples were diluted in $0.1 \mathrm{M}$ triethanolamine buffer ( $\mathrm{pH} 9.15)$ and then precipitated with $6 \mathrm{~N}$ trichloroacetic acid (10\%). L- and D-lactate levels in the supernatant were measured using an enzyme assay kit, according to the manufacturer's instructions (Biosentec, Toulouse, France). The results were expressed in $\mathrm{mmol} / \mathrm{L}$.

\subsection{Extraction and Amplification of DNA from SHIME ${ }^{\circledR}$ Samples}

Samples (0.20-0.25 mL) were collected from the three colon reactors on D0, D15 and D30, and immediately stored at $-80^{\circ} \mathrm{C}$. Each sample's total DNA was extracted as described by Godon [41]. The DNA was eluted in a final volume of $50 \mu \mathrm{L}$ and stored at $-20^{\circ} \mathrm{C}$. The DNA's concentration and intactness were determined visually after electrophoresis on a $1 \%$ agarose gel containing ethidium bromide. Total bacterial DNA and Bifidobacterium-specific DNA were amplified using HotStar Taq DNA polymerase (Qiagen, Courtaboeuf, France) and specific primer sets and temperature-time programs (Table 3 and Table S1). 
Table 3. Primers and temperature-time programs used in the Polymerase Chain Reaction (PCR) amplification for Temporal Temperature Gradient Gel Electrophoresis (TTGE) diversity analysis.

\begin{tabular}{lll}
\hline \multicolumn{1}{c}{ Primer } & \multicolumn{1}{c}{ Temperature-Time Program } & Specificity \\
\hline Bact 968-GC-f & $(1) 15 \ddot{E}^{\prime} ; 95^{\circ} \mathrm{C}$ & \\
Bact 1401-r & $(2) 1^{\prime} ; 97^{\circ} \mathrm{C} / 1^{\prime} ; 58^{\circ} \mathrm{C} / 1^{\prime} 30 ; 72^{\circ} \mathrm{C}(\times 30)$ & Bacteria \\
\hline & $(3) 15^{\prime} ; 72^{\circ} \mathrm{C}$ & \\
Bif 164-f & $(1) 15^{\prime} ; 95^{\circ} \mathrm{C}$ & Bifidobacterium spp. \\
Bif 662-GC-r & $(2) 1^{\prime} ; 97^{\circ} \mathrm{C} / 1^{\prime} ; 58^{\circ} \mathrm{C} / 1^{\prime} 30 ; 72{ }^{\circ} \mathrm{C}(\times 30)$ & \\
\hline
\end{tabular}

\subsection{Temporal Temperature Gradient Gel Electrophoresis (TTGE)}

PCR products were submitted to TTGE for sequence-specific separation using the DCode Universal Mutation Detection System (Bio-Rad, Paris, France), a $1 \mathrm{~mm}$-thick, $16 \times 16$ polyacrylamide gel (as described by [42]) and $7 \mathrm{~L}$ of $1.25 \times$ Tris-acetate-EDTA electrophoresis buffer. The electrophoresis was performed at a fixed voltage of $63 \mathrm{~V}$ for $15 \mathrm{~h}$, with an initial temperature of $66^{\circ} \mathrm{C}$ and a ramp rate of $0.3^{\circ} \mathrm{C} / \mathrm{h}$. The gel was stained in the dark by immersion for $30 \mathrm{~min}$ in a solution of SYBR Gold ${ }^{\circledR}$ Nucleic Acid Gel Stain (Invitrogen, Eugene, OR, USA) and was then read on a Storm device (Molecular Dynamics, Bondoufle, France). The TTGE profiles were analyzed with GelCompar software (version 2.0, Applied Maths, Kortrijk, Belgium) in order to determine (i) the number of bands in each lane; and (ii) each band's position and intensity. A principal component analysis (PCA) was used to identify patterns in data and to highlight similarities and differences. The degree of similarity between patterns was measured by calculating Pearson's coefficient.

\subsection{Real-Time Quantitative PCR (RT-qPCR) Analyses of Bacterial $16 S$ rDNA Genes}

Using the DNA extracted from SHIME ${ }^{\circledR}$ samples, qPCR assays for specific bacterial $16 \mathrm{~S}$ rRNA genes (with the primer and probes described in Table S1) [40] were used to determine the composition of the microbiota in each reactor on D0, D15 and D30. PCR inhibition was tested with DNA dilutions and the TaqMan exogenous internal positive control (Applied Biosytems, Carlsbad, CA, USA). No inhibition was detected in 1000-fold dilutions of the DNA; consequently, this dilution was used for all PCR amplifications. The RT-qPCR mixtures were amplified in an ABI PRISM 7000 system (Applied Biosystems). Total bacteria and the main bacterial groups (Clostridium coccoides, Clostridium leptum, Bacteroidetes/Prevotella, and Bifidobacterium) were detected using the TaqMan universal PCR system, whereas the subdominant bacterial groups (Escherichia coli and Lactobacillus/Leuconostoc/Pediococcus) were detected using the SYBR Green PCR system (Life Technologies, Saint Aubin, France). Standard curves generated from each specific reference strain [40] were used for quantification by plotting the cycle threshold $(\mathrm{Ct})$ versus the cell count in the RT-qPCR system. The results were expressed in copy number of $16 \mathrm{~S}$ rRNA gene per $\mathrm{mL}$ of microbioal biomass.

\subsection{Statistical Analysis}

Statistical analyses were performed with StatView software (version 5.0, Abacus Concepts Inc., Berkeley, CA, USA). Data were analyzed using non-parametric Kruskal-Wallis and Mann-Whitney tests. In all analyses, the threshold for statistical significance was set to $p<0.05$.

\section{Results}

\subsection{Bacterial Composition}

The effect of $1 \mathrm{mg} /$ day CPF in rapeseed oil on the gut microbiota cultured in vitro was analyzed for the SHIME ${ }^{\circledR \prime}$ s colon as a whole and in each of the three individual reactors at D0 (before CPF-oil exposure), D15 and D30. Total bacterial counts and the specific bacterial profile were determined by 
plate counting and qPCR. According to the qPCR results, counts of "all bacteria" were high and stable in all three reactors and at all three time points. The mean counts ranged from $11.0 \pm 0.4$ to $11.9 \pm 0.01$ $\log (16 \mathrm{~S}$ rRNA gene copy/mL of microbioal biomass). Treatment with CPF $1 \mathrm{mg} /$ day in oil did not appear to have any effect on the total bacteria load (Figure 1A). In contrast, and although the counts were always lower than those determined by $\mathrm{qPCR}$, the total bacteria load determined by plate counts increased during CPF 1 treatment (Figure 1B). Compared with D0, the total cultured bacterial count was significantly higher at D15 and D30 $(p<0.001)$ for the colon as a whole and at D30 for each of the colon compartments $(p<0.05)$ (Figure 1B). The mean cultured bacterial counts on D0 and D30 were $8.7 \pm 0.13$ and $9.9 \pm 0.11 \log (\mathrm{CFU} / \mathrm{mL})$, respectively. Thus, after 30 days of CPF 1-oil mg/day administration, both cultured aerobe and anaerobe counts were above the D0 value in the simulated colon as a whole $(p<0.001)$ and in its individual segments $(p<0.05)$ (Figure $1 C, D)$.
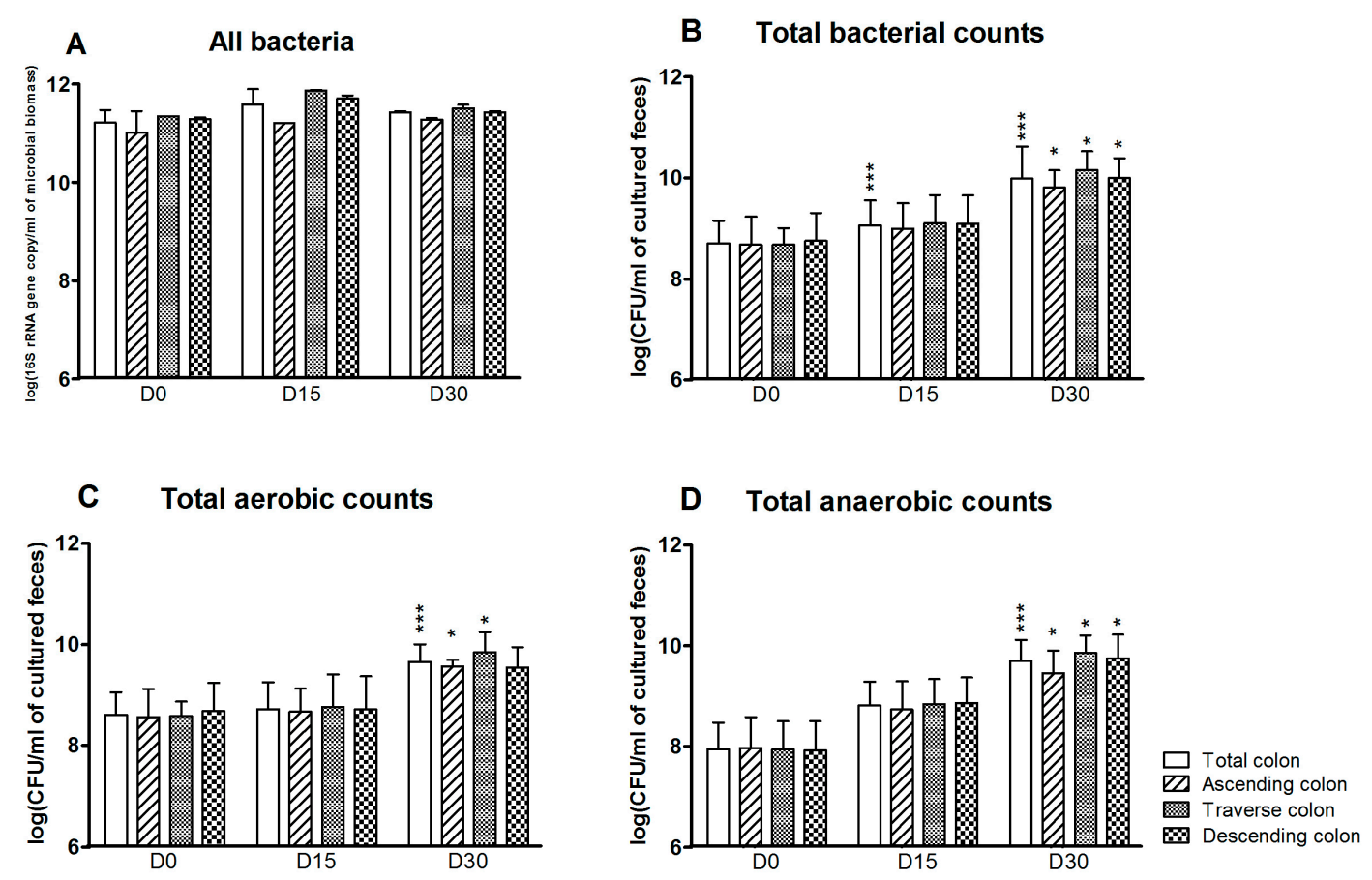

Figure 1. Total bacteria counts for the $\mathrm{SHIME}^{\circledR \prime}$ 's colon as a whole and for each of the individual colon reactors at the end of the control period (D0) and after 15 and 30 days of exposure to pesticide chlorpyrifos (CPF) $1 \mathrm{mg} /$ day in oil (D15 and D30). (A) Total bacterial counts determined by qPCR (Polymerase Chain Reaction) (log 16S rRNA gene copy/mL of microbioal biomass); (B) Total bacterial counts determined by plate culture (log CFU/mL of cultured feces); (C) Total cultured aerobe counts ( $\log$ CFU/mL of cultured feces); (D) Total cultured anaerobe counts (log CFU/mL of cultured feces). Data are expressed as the mean \pm Standard Deviation (SD) and were analyzed in a Kruskal Wallis test and then a Mann Whitney test. The level of statistical significance is indicated as follows: ${ }^{*} p<0.05$; $* * * p<0.001$.

According to the qPCR assays, the effect of CPF-oil treatment on Bacteroides/Prevotella groups at D15 and D30 varied from one colon reactor to another (Figure 2A). There was no change in the ascending colon reactor. However, CPF-oil exposure was associated with a reduction over time in the Bacteroides/Prevotella population in the transverse colon reactor (Figure 2A: D0: $10.9 \pm 0.05$; D15: $6.0 \pm 0.1$; D30: $6.5 \pm 0.1 \log (16 \mathrm{~S}$ rRNA gene copy $/ \mathrm{mL}$ of microbioal biomass $))$ and an increase in the descending reactor (D0: $6.7 \pm 0.1$; D15: $11.2 \pm 0.2$; D30: $10.8 \pm 0.02 \log (16 \mathrm{~S} \mathrm{rRNA}$ gene copy $/ \mathrm{mL}$ of microbioal biomass)) (Figure 2A). Based on plate counts, the Bacteroides spp. population increased significantly in the colon as a whole at D15 $(8.9 \pm 0.2(\log \mathrm{CFU} / \mathrm{mL}$ of cultured feces; $p<0.05))$ and D30 (9.7 \pm 0.1 ( $\log \mathrm{CFU} / \mathrm{mL}$ of cultured feces; $p<0.001)$ (Figure $2 \mathrm{~B})$. In contrast, the molecular assay showed that exposure to CPF $1 \mathrm{mg}$ /day in oil was associated with a light decrease in the bifidobacteria 
population in the colon as a whole at D15 only (D0: $8.2 \pm 0.1$; D15: $7.6 \pm 0.4 \log (16 \mathrm{~S}$ rRNA gene copy $/ \mathrm{mL}$ of microbioal biomass)). The impact was greater in the descending reactor at both D15 and D30 (Figure 2C). According to the culture method, a significant decrease in the bifidobacteria population was observed at D30 in the colon as a whole (D0: $7.9 \pm 0.2 ; \mathrm{D} 30: 7.1 \pm 0.2(\log \mathrm{CFU} / \mathrm{mL}$ of cultured feces; $(p<0.05)$ )) (Figure 2D). In targeted molecular analyses, levels of the Clostridium coccoides and Clostridium leptum clusters were below the detection threshold-indicating that these extremely oxygen-sensitive bacteria were not alive (data not shown). In contrast, the Clostridium spp. count as determined by plate culture increased in the colon as a whole during CPF-oil exposure (D0: 7.9 \pm 0.2 ; D15: $9.0 \pm 0.2 ; \mathrm{D} 30: 9.6 \pm 0.2 \log \mathrm{CFU} / \mathrm{mL}$ of cultured feces; Figure 2E).
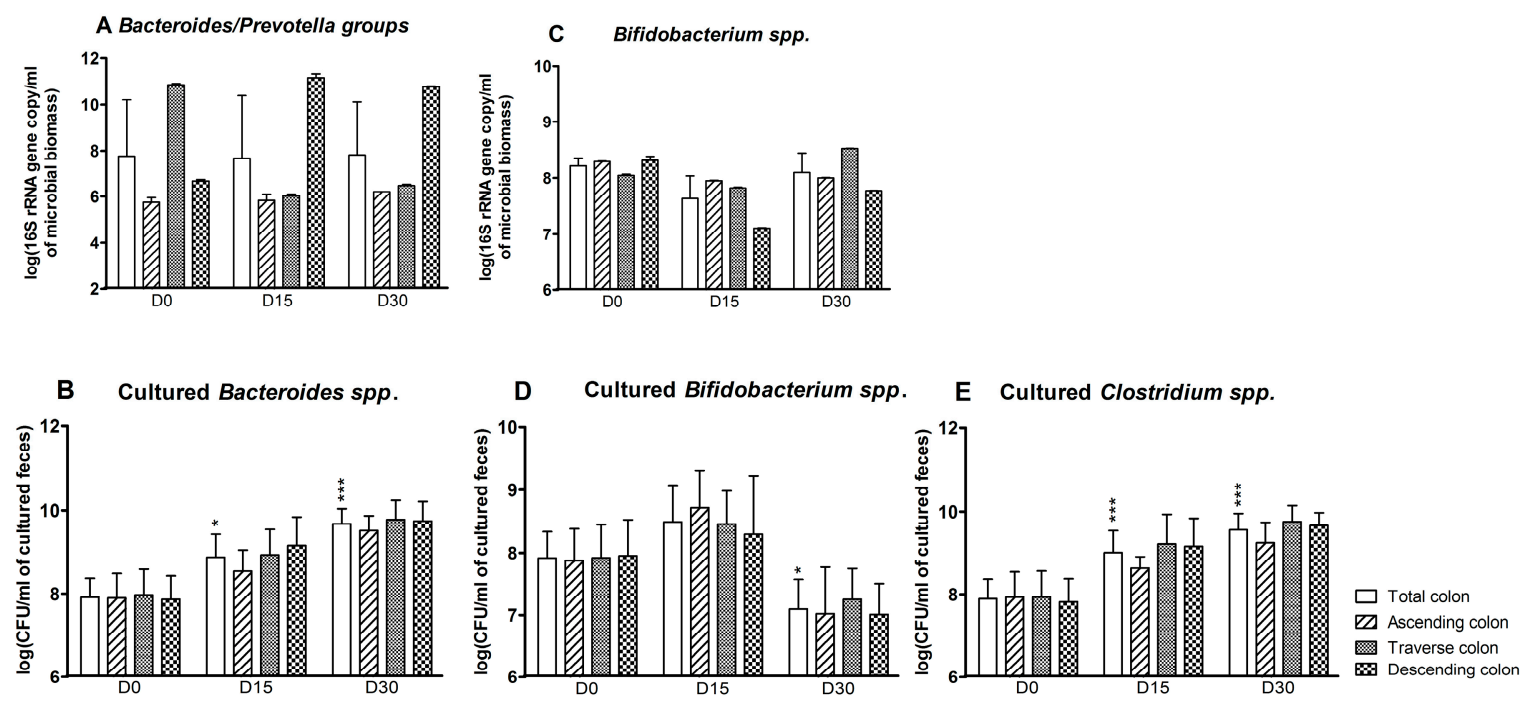

Figure 2. Anaerobe counts for the $\mathrm{SHIME}^{\circledR}$ 's colon as a whole and for each of the individual colon reactors at the end of the control period (D0) and after 15 and 30 days of exposure to CPF $1 \mathrm{mg} /$ day in oil (D15 and D30). (A) Bacteroides/Prevotella groups determined by qPCR (log 16S rRNA gene copy/mL of microbioal biomass); (B) cultured Bacteroides spp. counts (log CFU/mL of cultured feces); (C) bifidobacterial counts determined by qPCR ( $\log 16 \mathrm{~S}$ rRNA gene copy/mL of microbioal biomass); (D) cultured bifidobacterial counts ( $\log \mathrm{CFU} / \mathrm{mL}$ of cultured feces); and (E) cultured Clostridium spp. counts $(\log \mathrm{CFU} / \mathrm{mL}$ of cultured feces). Data are expressed as the mean $\pm \mathrm{SD}$ and were analyzed in a Kruskal Wallis test and then a Mann Whitney test. The level of statistical significance is indicated as follows: ${ }^{*} p<0.05 ;{ }^{* *} p<0.001$.

Some aerobic bacterial populations were also affected by exposure to CPF in rapeseed oil (Figure 3). The E. coli count was greater at D15 and D30 in the colon as a whole (D0: $10.2 \pm 0.4 ; \mathrm{D} 15: 11.0 \pm 0.8$; D30: $10.8 \pm 0.4 \log (16 \mathrm{~S}$ rRNA gene copy/mL of microbioal biomass)). The strongest effects were observed in the transverse and descending reactors (Figure 3A). The Enterobacteria plate counts (which target more genera-E. coli, Klebsiella spp., or Citrobacter spp., for example-than the molecular method) in the colon were significantly greater at D15 and D30 ( $<<0.001)$ (Figure 3B). In contrast, exposure to CPF-oil treatment had no impact on the Lactobacillus/Leuconostoc counts as assessed by qPCR or plate counts (Figure 3C,D).

In summary, CPF-oil treatment affects the gut microbiota in vitro, although there is some discordance between the culture-dependent and culture-independent analyses. Exposure to $1 \mathrm{mg} /$ day CPF dissolved in rapeseed oil was associated with a decrease in the colonic bifidobacterial population at D15 and an increase in the colonic E. coli count at D30 (according to qPCR data). Conventional plate culture techniques showed a rise in the total bacterial count, which reflected an increase in Bacteroides spp., Clostridium spp. and enterobacterial populations at D15 and D30 and a decrease in the bifidobacterial count at D30. 

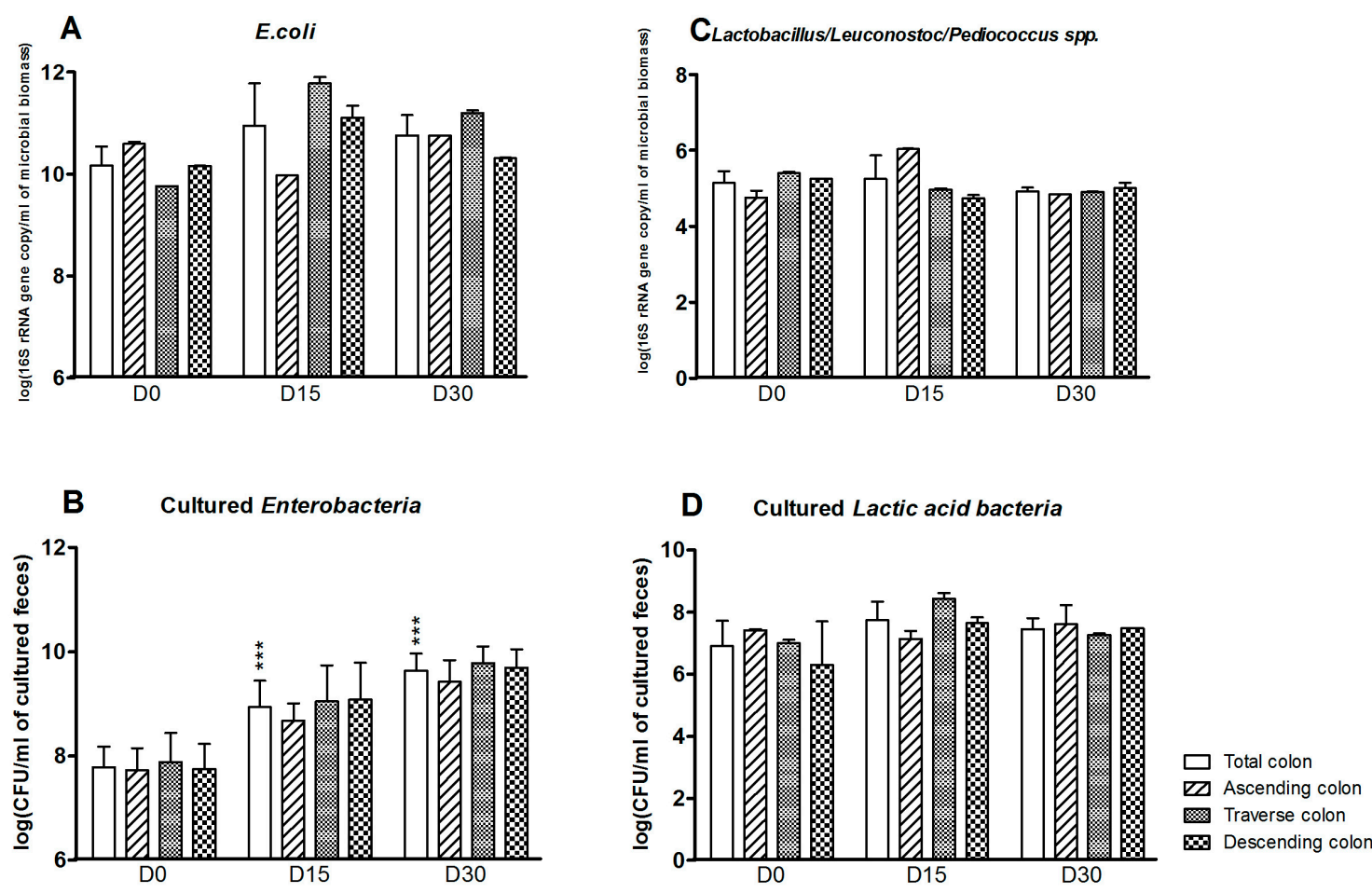

Figure 3. Aerobe counts for the $\mathrm{SHIME}^{\circledR}$ 's colon as a whole and for each of the individual colon reactors at the end of the control period (D0) and after 15 and 30 days of exposure to CPF $1 \mathrm{mg} /$ day in oil (D15 and D30). (A) E. coli counts determined by qPCR (log 16S rRNA gene copy /mL of microbioal biomass); (B) Cultured enterobacterial counts (log CFU/mL of cultured feces); (C) Lactobacillus/Leuconostoc/Pediococcus counts determined by qPCR (log 16S rRNA gene copy/mL of microbioal biomass); (D) Cultured LAB counts (log CFU/mL of cultured feces). Data are expressed as the mean \pm SD and were analyzed in a Kruskal Wallis test and then a Mann Whitney test. The level of statistical significance is indicated as follows: ${ }^{* * *} p<0.001$.

\subsection{Bacterial Diversity}

As slight quantitative differences in total bacteria and bifidobacterial counts were observed in the SHIME ${ }^{\circledR}$ 's compartments, we next sought to determine whether exposure to CPF $1 \mathrm{mg} /$ day in oil was associated with changes in bacterial diversity. As previously demonstrated using two different techniques, the microbiota's composition and diversity stabilize 2 weeks after starting up the SHIME ${ }^{\circledR}$ [38]. Thus, we used PCR-TTGE to assess and compare the molecular compositions of microbial populations from the different colon compartments on D0, D15 and D30. Indeed, the fingerprint for total bacteria reflected an impact of CPF-oil exposure. On D0 (before CPF exposure), all three colon compartments had similar TTGE band profiles. The Pearson dendrogram and the PCA also showed that the bacterial compositions in the three colon compartments were very similar on D0 (Figure 4). In contrast, the TTGE profiles for D15 and D30 samples differed from those observed on D0 (Figure 4). The Pearson dendrogram and the PCA showed that samples at D15 and D30 were similar in molecular terms and therefore similar in terms of bacterial diversity. Indeed, the Pearson coefficients for the band patterns ranged from $74.8 \%$ to $93.4 \%$ on D0 and from $77.3 \%$ to $91.2 \%$ on D15 and D30 (Figure 4B). On D30, the descending colon's diversity profile differed markedly from those in the two other reactors (Figure 4C).

Given that bifidobacteria are an important bacterial group for human health, we next used a bifidobacterium-specific PCR assay to study the diversity of this group (Figure 5). Exposure to CPF $1 \mathrm{mg} /$ day in oil was not associated with changes in the Bifidobacterium community (Figure 5A). Nonetheless, the TTGE data showed that the ascending colon reactor was less diverse than the transverse and descending colon reactors (Figure 5A). All the samples from the ascending colon 
clustered into one group, whereas the samples from the transverse and descending colon reactors clustered into another group (Figure 5B,C). The Pearson coefficients for the band patterns ranged from $93.1 \%$ to $96.4 \%$ for the ascending colon and from $70.7 \%$ and $92.6 \%$ for the other reactors. In a PCA, the gel patterns from the transverse and descending vessels differed from that observed in the ascending colon (at both D15 and D30), and thus reflected a slight effect of CPF-oil exposure on bifidobacterial diversity (Figure 5C).

A

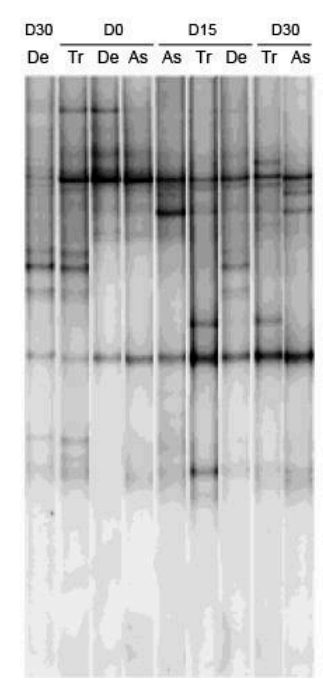

в

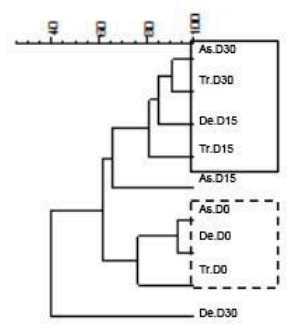

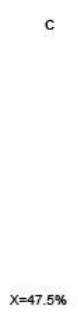

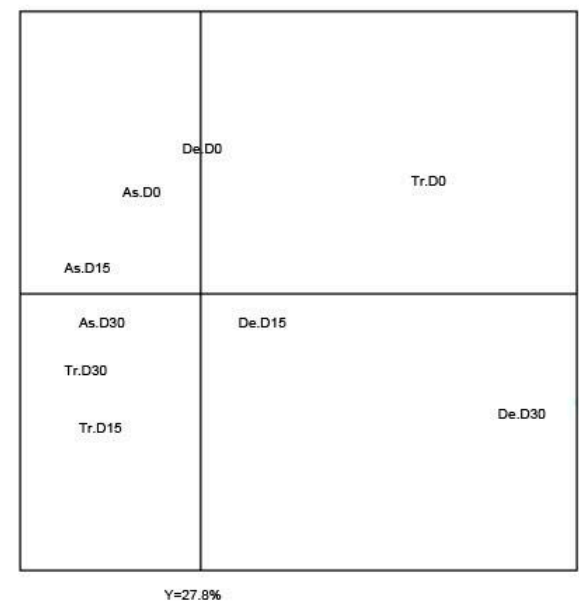

Figure 4. The Temporal Temperature Gradient Gel Electrophoresis (TTGE) fingerprint for total bacteria in the three colon reactors after 0,15 and 30 days of exposure to CPF $1 \mathrm{mg} /$ day in oil (D0, D15 and D30, respectively). (A) TTGE of all bacterial $16 \mathrm{~S}$ rRNA gene amplicons in fecal samples collected from the colon vessels (As: ascending; Tr: transverse; De: descending); (B) The Pearson dendrogram for samples from each reactor at D0, D15 and D30; (C) The results of a PCA of samples from each reactor. The $\mathrm{x}$ and y values were $47.5 \%$ and $27.8 \%$, respectively.

A
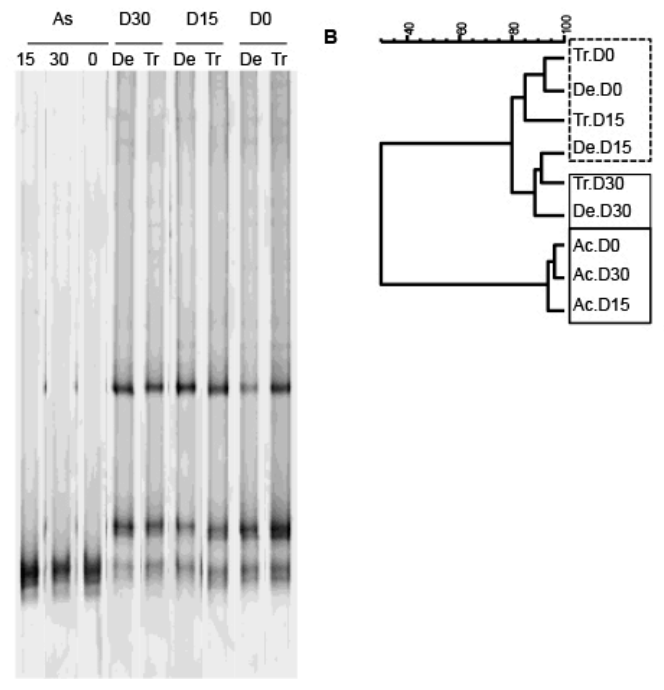

c

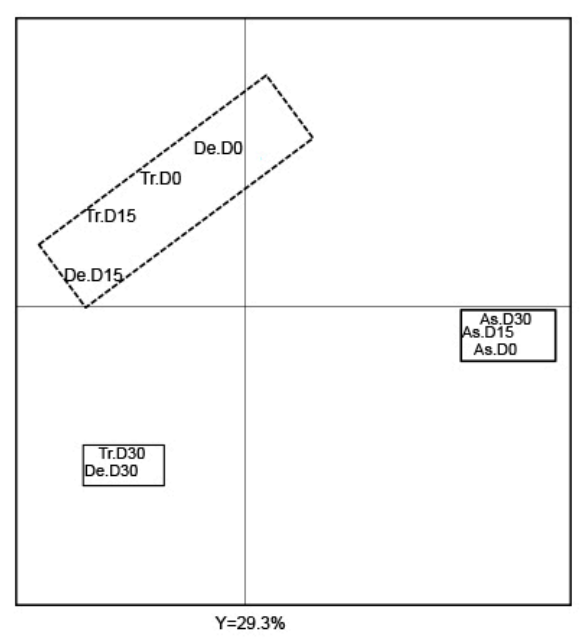

Figure 5. The TTGE fingerprint for bifidobacteria in the three colon reactors after 0,15 and 30 days of exposure to CPF $1 \mathrm{mg} /$ day in oil (D0, D15 and D30, respectively). (A) TTGE of bifidobacterial $16 \mathrm{~S}$ rRNA gene amplicons of fecal samples taken from the colon vessels (As: ascending; Tr: transverse; De: descending); (B) The Pearson dendrogram for the reactor samples at D0, D15 and D30; (C) Results of a PCA of the samples from each reactor. The $x$ and $y$ values were $60.9 \%$ and $29.3 \%$, respectively. 
In summary, exposure to CPF $1 \mathrm{mg}$ /day in rapeseed oil altered the total bacteria diversity in the different vessels by D15, whereas the pesticide-oil's effect on the bifidobacterial population in the transverse and descending colon reactors was only apparent on D30. These changes were relatively specific to the different colon compartments.

\subsection{Levels of Bacterial Metabolites}

An increase in $\mathrm{pH}$ during the control period (from D-14 to D0) and during the first 15 days of exposure to CPF-oil treatment (from D0 to D15) was observed in the SHIME ${ }^{\circledR \prime}$ s colon as a whole (Figure 6A) and in each of the three component reactors (Figure 6B). Between D15 and D30, all the $\mathrm{pH}$ values stabilized at around 6 (Figure 6A,B).

Exposure to CPF $1 \mathrm{mg} /$ day in rapeseed oil did not have any significant effect on total SCFA production in any reactor or at any time point (Table 4). For the colon as a whole, exposure to CPF in oil was associated with a decrease in acetate and butyrate levels and an increase in propionate levels on D15; neither of these changes were statistically significant. However, the acetate and butyrate levels had essentially returned to their pre-exposure levels on D30. In the ascending colon, acetate production tended to increase gradually following CPF-oil exposure (D0: $14.2 \pm 0.1$; D15: $16.4 \pm 1.1$; D30: $18.2 \pm 0.2 \mathrm{mmol} / \mathrm{L}$ ). For the transverse and descending colon vessels, a large fall in acetate levels was seen at D15. However, this effect was only transient because the levels had fallen below the D0 value at D30 for the transverse colon (D0: $39.7 \pm 0.02 ; \mathrm{D} 30$ : $35.1 \pm 0.03 \mathrm{mmol} / \mathrm{L}$ ) and had risen above the D0 value at D30 for the descending colon (D0: $27.0 \pm 0.7$; D30: $47.6 \pm 0.02 \mathrm{mmol} / \mathrm{L}$ ). Interestingly, $\mathrm{CPF}$-oil treatment had the opposite effect on propionate production in the transverse and descending vessels. Indeed, it tended to decrease in the transverse colon and increase in the descending colon. The pesticide's effect on butyrate production was similar in the transverse and descending colon reactors: a decrease in production at D15 and an increase at D30 were observed in both vessels.

Levels of branched SCFAs (protein metabolites) were also impacted by exposure to CPF $1 \mathrm{mg} /$ day in oil. In the ascending and transverse reactors, the level had decreased by D15 but had returned to the D0 value by D30. In contrast, the level of branched SCFAs increased gradually in the descending colon reactor. The production of L-lactate decreased after 30 days of CPF-oil exposure $(p<0.01)$, whereas D-lactate levels increased significantly in the colon as a whole $(p<0.05)$ (Table 4$)$. In the ascending colon, the L-lactate level increased on D15 $(p<0.05)$ and decreased at D30, while D-lactate level decreased until D30 $(p<0.05)$. In the transverse colon reactor, the L-lactate level decreased at D15 and increased at D30 $(p=0.06)$ while the D-lactate increased until D30 $(p<0.05)$. Lastly, in the descending colon reactor, levels of both L- and D-lactate falled at D15 and D30 $(p<0.05)$ (Table 4).
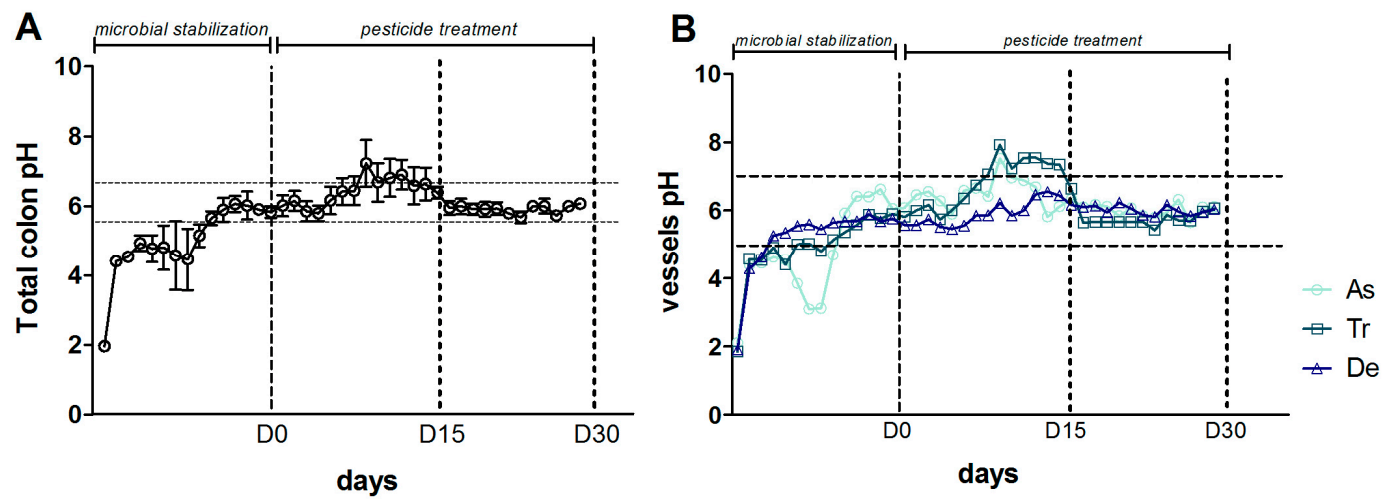

Figure 6. Change over time in the $\mathrm{pH}$ during the CPF1-oil treatment period (DO, D15 and D30) in (A) the colon as a whole (the mean value for the three colon reactors); and (B) each individual colon reactor. 
Table 4. Concentrations of SCFA and L- and D-lactate in the colon as a whole and in each individual colon vessel for the control time point (D0) and during the treatment period (D15 and D30).

\begin{tabular}{|c|c|c|c|c|c|c|c|c|c|c|c|c|}
\hline \multirow{2}{*}{$\begin{array}{c}\text { Vessel } \\
\text { Time point }\end{array}$} & \multicolumn{3}{|c|}{ Ascending } & \multicolumn{3}{|c|}{ Transverse } & \multicolumn{3}{|c|}{ Descending } & \multicolumn{3}{|c|}{ Colon } \\
\hline & D0 & D15 & D30 & D0 & D15 & D30 & Do & D15 & D30 & D0 & D15 & D30 \\
\hline Total SCFA (mM) & $15.3 \pm 0.1$ & $17.1 \pm 0.3$ & $19.3 \pm 0.2$ & $49.7 \pm 0.1$ & $6.6 \pm 0.5$ & $38.6 \pm 0.1$ & $29 \pm 0.6$ & $22.8 \pm 0.003$ & $58.7 \pm 0.02$ & $31.3 \pm 12.3$ & $15.7 \pm 6.1$ & $38.9 \pm 8.9$ \\
\hline Acetate & $14.2 \pm 0.1$ & $16.4 \pm 1.1$ & $18.2 \pm 0.2$ & $39.7 \pm 0.02$ & $5.6 \pm 0.5$ & $35.1 \pm 0.03$ & $27 \pm 0.7$ & $14.7 \pm 0.7$ & $47.6 \pm 0.02$ & $27 \pm 8.7$ & $15.5 \pm 4.4$ & $33.6 \pm 10.2$ \\
\hline Propionate & $0.8 \pm 0.01$ & $1.34 \pm 0$ & $0.9 \pm 0.04$ & $7.9 \pm 0.01$ & $0.9 \pm 0.1$ & $1.2 \pm 0.001$ & $0.8 \pm 0.08$ & $8 \pm 0.07$ & $9.2 \pm 0.08$ & $3.2 \pm 3.1$ & $4.7 \pm 3.1$ & $3.8 \pm 3.6$ \\
\hline Butyrate & $0.1 \pm 0.1$ & $0.1 \pm 0.0$ & $0.1 \pm 0.004$ & $2 \pm 0.03$ & $0.1 \pm 0.004$ & $2.2 \pm 0.03$ & $1.2 \pm 0.02$ & $0.1 \pm 0.01$ & $1.8 \pm 0.01$ & $1.1 \pm 07$ & $0.1 \pm 0.01$ & $1.4 \pm 0.8$ \\
\hline Valerate & $0.06 \pm 0.01$ & $0.0 \pm 0.0$ & $0.01 \pm 0.0$ & $0.1 \pm 0.001$ & $0.0 \pm 0.0$ & $0.0 \pm 0.0$ & $0.01 \pm 0.0$ & $0.0 \pm 0.0$ & $0.1 \pm 0.02$ & $0.05 \pm 0.02$ & $0.0 \pm 0.0^{*}$ & $0.1 \pm 0.05$ \\
\hline Caproate & $0.08 \pm 0.02$ & $0.0 \pm 0.0$ & $0.02 \pm 0.0$ & $0.05 \pm 0.01$ & $0.0 \pm 0.0$ & $0.04 \pm 0.003$ & $0.04 \pm 0.0$ & $0.0 \pm 0.0$ & $0.04 \pm 0.002$ & $0.06 \pm 0.01$ & $0.0 \pm 0.0^{* *}$ & $0.04 \pm 0.001$ ** \\
\hline Total Branched SCFA & $0.1 \pm 0.02$ & $0.01 \pm 0.01$ & $0.07 \pm 0.02$ & $0.8 \pm 0.01$ & $0.0 \pm 0.0$ & $0.7 \pm 0.01$ & $0.1 \pm 0.1$ & $0.6 \pm 0.001$ & $0.7 \pm 0.01$ & $0.4 \pm 0.3$ & $0.3 \pm 0.3$ & $0.3 \pm 0.004$ \\
\hline L-lactate (mM) & $1.4 \pm 0.1$ & $2 \pm 0.1^{*}$ & $0.3 \pm 0.1^{*}$ & $0.07 \pm 0.0$ & $0.0 \pm 0.0$ & $0.2 \pm 0.03$ & $0.5 \pm 0.02$ & $0.0 \pm 0.0^{*}$ & $0.0 \pm 0.0^{*}$ & $0.7 \pm 0.5$ & $2 \pm 0.1$ & $0.3 \pm 0.1 * *$ \\
\hline D-lactate $(\mathrm{mM})$ & $1.7 \pm 0.1$ & $3.2 \pm 0.1^{*}$ & $7.3 \pm 0.2 *$ & $0.2 \pm 0.1$ & $0.2 \pm 0.04$ & $2.4 \pm 0.1^{*}$ & $0.6 \pm 0.03$ & $0.2 \pm 0.1^{*}$ & $0.5 \pm 0.1$ * & $0.8 \pm 0.6$ & $1.2 \pm 1.4$ & $3.4 \pm 2.6^{*}$ \\
\hline
\end{tabular}

Data are expressed as the mean \pm Standard Deviation (SD). SCFA and lactate concentrations in the suspension (in mM). Values were compared in a Mann-Whitney test,

SCFA $=$ short-chain fatty acids. Signification * $p<0.05, * * p<0.01$. 
In summary, exposure to CPF $1 \mathrm{mg} /$ day in oil slightly altered the fermentative activity of the human cultured microbiota. Firstly CPF $1 \mathrm{mg} /$ day in oil modulated acetate, propionate and branched SCFA production in the transverse and descending colon vessels. Secondly, a low dose of CPF in oil mostly altered L- and D-lactate production in the ascending colon. L-lactate production peaked at D15 and fell by D30. In contrast, the D-lactate level increased with the CPF 1-oil treatment and peaked at D30 in the ascending colon vessel.

\section{Discussion}

Over the years, a range of in vitro models of the human intestinal tract have been developed [43-45]. In all these models, samples can be collected from each fermenter in order to investigate the exact location of metabolic transformations. However, these models only represent some of the specific physical aspects of the digestive tract and thus do not reflect the full range of physiological interactions between the microbiota and the host. Another limitation relates to the difficulty of obtaining sufficient replicates of a treatment under comparable conditions. Indeed, the best results are obtained if the same fecal slurry is used in all treatments. However, the burdensome nature of the equipment involved makes it difficult to run multiple systems in parallel with the same fresh fecal sample. One way of overcoming this problem (at least in part) is to sample multiple aliquots during each run. In contrast, major advantages of these in vitro systems include their similitude to the human in vivo context and the lack of a requirement for the ethical approval of experiments.

Our present results showed that 30 days of chronic exposure to a low dose of CPF (dissolved in oil) in an in vitro model of the human gut was associated with changes in the bacterial microbiota's composition, diversity and fermentative activity. By applying conventional bacterial culture methods and molecular biology techniques, we found that the pesticide had a greater impact on viable/culturable bacteria than on total bacteria. The two methods gave different quantitative results. In general, conventional culture methods provide an estimate of the number of viable/culturable bacteria, which account for $20 \%$ to $40 \%$ of the intestinal microbiota [46]. Molecular techniques take account of the entire targeted bacterial population (which includes viable, non-culturable and inactive bacteria) and have a lower detection threshold than culture techniques. However, one inherent drawback of molecular methods (relative to culture techniques) relates to the use of specific primers and probes for a given bacterial group population. In contrast, molecular methods are able to detect unculturable or poorly culturable bacteria, such as the extremely oxygen-sensitive Clostriduim leptum. The concomitant use of these two approaches strengthened our data. For example, the MRS medium enabled the growth of LAB (such as streptococci and lactococci) as well as lactobacilli. This lack of selectivity might explain the two-log difference between the counts derived respectively by culture techniques and qPCR assays for this target population. Despite this difference, the results generated by the two techniques suggested that exposure to CPF-oil treatment did not have a significant impact on LAB in general and lactobacilli in particular. It has been reported that LAB isolated from the intestine [47] and from a Korean food preparation [48] were able to use CPF as a source of carbon and phosphate. Joly et al. (2013) reported a decrease in the number of lactobacilli in a similar in vitro model of the human gut [28]. However, the latter study only monitored lactobacilli, whereas the present study took account of all the LAB (given our use of MRS medium); this might explain the discrepancy between the two sets of results. Moreover, the studies showing that LAB use CPF as a carbon source were based on a simple model (isolated bacteria) or analyzed a food matrix; these are not dynamic, complex ecosystems like the one studied in the SHIME ${ }^{\circledR}$. This aspect might explain the observed differences with regard to our results for the lactobacilli. In an earlier study, Joly et al., found that a decrease in the lactobacilli leads to a $\mathrm{pH}$ increase (a change from an acid $\mathrm{pH}$ to a basic $\mathrm{pH}$ ) [28]. The dysbiosis favored other bacteria, such as E. coli. We nevertheless observed that the bifidobacterial count (as measured with conventional culture and a molecular method) fell after 30 days of CPF exposure, as previously reported by Joly et al. [28]. Since CPF is generally degraded by facultative aero-anaerobic bacteria $[49,50]$, the increase in Enterobacteria counts (determined either by culture or a 
qPCR assay for E. coli) after 30 days of exposure might be a good marker of CPF metabolism. This increase might be stimulated by a CPF-induced rise in $\mathrm{pH}$, since Enterobacteria are poorly tolerant of acidic conditions [51]. The 1-to-2 log difference in the counts determined with conventional vs. molecular techniques might be due to our choice of culture medium, which enabled the growth of all enteric bacteria. In contrast, our qPCR analysis of $C$. coccoides and C. leptum indicated that the numbers of these bacteria were below the detection limit (data not shown), whereas the conventional culture method revealed an increase in the population of clostridia after only 15 days of CPF exposure. The genus Clostridium includes a very large number of species, and the culture technique is less restrictive than the qPCR assay (which targets only two of the 19 Clostridium clusters) [52]. Regardless of these technical aspects, we found that chronic exposure to CPF-oil treatment induced a larger change in the population of viable/culturable bacteria. However, the changes in the bacterial community in the different parts of the in vitro intestinal model were also observed (albeit to a lesser extent) using molecular methods. As a consequence, we next determined whether CPF-oil treatment also impacted the diversity of the bacterial community. The TTGE molecular technique was used to monitor qualitative changes in bacterial composition in the different colon reactors and thus provided a dynamic overview of the diversity of the dominant bacterial species. A TTGE analysis of the total microbial population revealed an effect of CPF-oil exposure on total bacterial diversity, as indicated by the presence or absence of amplicons and differences in amplicon intensity in the different compartments of the simulated gut. On D0, the diversity was much the same in the three colon reactors, whereas the profiles of the ascending and transverse segments were relatively similar during the period of CPF-oil exposure. However, the diversity of the descending colon differed from that of the other two segments. Given that (i) quantitative analyses showed a decrease in the bifidobacterial count following CPF-oil exposure; and (ii) many bifidobacteria are classified as probiotics and have value in health outcomes, we also looked at the CPF treatment's effect on Bifidobacterium diversity. The TTGE results depended on the compartment; there was less diversity in the ascending colon than in the transverse and descending segments. However, a PCA placed the transverse and descending segments in separate groups; 30 days of CPF-oil exposure appeared to have different effects on the ascending colon vs. the transverse and descending parts of the colon. The gastrointestinal tract's microbial population has an important role in health because it modulates the colon's digestive functions by producing SCFAs [53]. The measurement of metabolite levels provides important information on the microbiota's functional status. An increase in $\mathrm{pH}$ was observed during the first 15 days of $\mathrm{CPF}$-oil exposure. The subsequent slight fall in the $\mathrm{pH}$ might be due to the microflora's metabolic adaptation to CPF exposure. The fermentation activity in the colon as a whole indicated that CPF-oil treatment had a transient inhibitory effect on acetate and butyrate at D15. Propionate and L-lactate levels increased at D15 and decreased at D30. L-lactate is mainly produced by Bifidobaterium and Lactobacillus, although the numbers of bifidobacteria (but not lactobacilli) fell during CPF-oil exposure. The gradual increase in the D-lactate level during CPF-oil exposure might be due to the increase in the Bacteroides count observed using culture methods. Indeed, Bacteroides spp. and lactobacilli are able to produce D-lactate [54]. In general, neither isomer is found in the feces of healthy individuals because both lactate isomers are either absorbed by colonocytes or metabolized into SCFAs by the gut bacteria $[55,56]$. The accumulation of D-lactate in feces reportedly reflects dysbiosis of the intestinal microbiota in short bowel syndrome [40]. The metabolic activity varied from one segment of the colon to another. For example, CPF-oil treatment has a very weak impact on bacterial fermentation in the ascending colon (relative to other colonic segments) which (due to the lower $\mathrm{pH}$ ) is the main site of metabolic activity [51]. However, we observed a gradual increase in acetate and D-lactate levels and a decrease in the L-lactate level. The transverse colon had a very high $\mathrm{pH}$ over the first 15 days of CPF-oil exposure. This led to a transient decrease in fermentative activity and a drop in the release of L-lactate and the main SCFAs. However, the D-lactate level had increased in the transverse colon after 30 days of CPF-oil exposure. A high $\mathrm{pH}$ might explain the increase in Bacteroides spp. counts, as measured by plate culture [51]. Lastly, the descending colon seemed to be more metabolically active than the other segments, as reflected by an increase in acetate, 
propionate and branched chain fatty acids. However, the levels of L and D-lactate in this compartment fell-probably because lactates are intermediates in the production of SCFAs [40,57]. The concomitant increase in propionate levels and decrease in lactate levels might be due to the increase in numbers of lactate-consuming bacteria, such as Eubacterium halli, Anaerostipes caccae, Coprococcus calus and the clostridia (notably those from cluster IX, which are able to produce propionate from lactate $[17,58]$ ).

By using the SHIME ${ }^{\circledR}$ model, we characterized the effect of chronic exposure to a low dose of $\mathrm{CPF}$ in oil on the human intestinal microbiota and on bacterial metabolism. Exposure to CPF in oil was associated with changes in several aspects of the intestinal microbiota (quantity, diversity and functionality). This model provides valuable information on intestinal microbial ecology, which is not addressed by other models (such as pure cultures) [59]. Given the current lack of in vitro models of bacterium-host cell interactions, it would be interesting to use other models to study the impact of pesticide exposure in a more integrated way [60]. Although the changes in our in vitro human model were not extremely pronounced, they do suggest that CPF has several effects on the human microbiota, and one can legitimately wonder whether these effects might be accentuated in immature organisms (such as newborns and infants). Indeed, Joly Condette et al.'s studies [10,11] showed that pesticide exposure had a greater effect (in terms of intestinal morphological changes, permeability and microbial imbalance) on rats during the weaning period than at adulthood. Hence, it would be very interesting to study the effects of pesticide exposure on a child's intestinal microbiota by using a "Baby-SHIME" ${ }^{\circledR}$ model [43]. It now clear that in order to improve the assessment of toxic risks associated with environmental contaminants, we need to study the latter's potentially harmful effects on the intestinal microbiota—a key "organ" for the individual's health.

\section{Conclusions}

Chronic exposure to food contaminants (including pesticides) is now a major societal concern. Our results show for the first time that chronic exposure to CPF in oil can directly alter human microbiota in terms of quantity, diversity and metabolic activity. Our results may open up new perspectives for assessing the toxic effects of contaminants on the intestinal microbiota-a key "organ" in individual health. Studies of how pure cultures (a simplified system) might be affected by CPF could also provide mechanistic information on dysbiosis of the microbiota and possible impacts on human health.

Supplementary Materials: The following are available online at www.mdpi.com/1660-4601/13/11/1088/s1. Table S1: Concentration of SCFA and L- and D- lactate in the colon as whole measured for the control time point (D0) and during the treatment period (D15, D30).

Acknowledgments: The authors thank David Fraser (Biotech Communication SARL, Damery, France) for editorial assistance. The authors also thank the Picardy Regional Council for providing funding.

Author Contributions: Hafida Khorsi Cauet, Flore Depeint, Latifa Abdennebi Najar and Véronique Bach designed the research program; Claire Joly Condette, Flore Depeint and Hafida Khorsi Cauet conceived and designed the experiments; Julie Reygner, Claire Joly Condette, Camille Mayeur, Aurélia Bruneau and Larbi Rhazi performed the experiments; Julie Reygner, Claire Joly Condette, Camille Mayeur, Aurélia Bruneau and Véronique Bach analyzed the data; Stéphane Delanaud contributed materials and analysis tools; Julie Reygner, Claire Joly Condette, Camille Mayeur and Hafida Khorsi Cauet wrote the manuscript; all authors evaluated and revised the manuscript.

Conflicts of Interest: The authors declare no conflict of interest.

\section{References}

1. Jaacks, L.M.; Staimez, L.R. Association of persistent organic pollutants and non-persistent pesticides with diabetes and diabetes-related health outcomes in Asia: A systematic review. Environ. Int. 2015, 76, 57-70. [CrossRef] [PubMed]

2. Nougadère, A.; Sirot, V.; Kadar, A.; Fastier, A.; Truchot, E.; Vergnet, C.; Hommet, F.; Baylé, J.; Gros, P.; Leblanc, J.-C. Total diet study on pesticide residues in France: Levels in food as consumed and chronic dietary risk to consumers. Environ. Int. 2012, 45, 135-150. [CrossRef] [PubMed] 
3. Zhang, Y.; Han, S.; Liang, D.; Shi, X.; Wang, F.; Liu, W.; Zhang, L.; Chen, L.; Gu, Y.; Tian, Y. Prenatal exposure to organophosphate pesticides and neurobehavioral development of neonates: A birth cohort study in Shenyang, China. PLoS ONE 2014, 9, e88491. [CrossRef] [PubMed]

4. Kwong, T.C. Organophosphate pesticides: Biochemistry and clinical toxicology. Ther. Drug Monit. 2002, 24, 144-149. [CrossRef] [PubMed]

5. Eaton, D.L.; Daroff, R.B.; Autrup, H.; Bridges, J.; Buffler, P.; Costa, L.G.; Coyle, J.; McKhann, G.; Mobley, W.C.; Nadel, L.; et al. Review of the toxicology of chlorpyrifos with an emphasis on human exposure and neurodevelopment. Crit. Rev. Toxicol. 2008, 38, 1-125. [CrossRef] [PubMed]

6. Saunders, M.; Magnanti, B.L.; Correia Carreira, S.; Yang, A.; Alamo-Hernández, U.; Riojas-Rodriguez, H.; Calamandrei, G.; Koppe, J.G.; Krayer von Krauss, M.; Keune, H.; et al. Chlorpyrifos and neurodevelopmental effects: A literature review and expert elicitation on research and policy. Environ. Health 2012, 11. [CrossRef] [PubMed]

7. Venerosi, A.; Tait, S.; Stecca, L.; Chiarotti, F.; De Felice, A.; Cometa, M.F.; Volpe, M.T.; Calamandrei, G.; Ricceri, L. Effects of maternal chlorpyrifos diet on social investigation and brain neuroendocrine markers in the offspring-A mouse study. Environ. Health 2015, 14. [CrossRef] [PubMed]

8. Cook, T.J.; Shenoy, S.S. Intestinal permeability of chlorpyrifos using the single-pass intestinal perfusion method in the rat. Toxicology 2003, 184, 125-133. [CrossRef]

9. Leoni, C.; Balduzzi, M.; Buratti, F.M.; Testai, E. The contribution of human small intestine to chlorpyrifos biotransformation. Toxicol. Lett. 2012, 215, 42-48. [CrossRef] [PubMed]

10. Joly Condette, C.; Khorsi-Cauet, H.; Morlière, P.; Zabijak, L.; Reygner, J.; Bach, V.; Gay-Quéheillard, J. Increased gut permeability and bacterial translocation after chronic chlorpyrifos exposure in rats. PLoS ONE 2014, 9, e102217. [CrossRef] [PubMed]

11. Joly Condette, C.; Bach, V.; Mayeur, C.; Gay-Quéheillard, J.; Khorsi-Cauet, H. Chlorpyrifos Exposure During Perinatal Period Affects Intestinal Microbiota Associated with Delay of Maturation of Digestive Tract in Rats. J. Pediatr. Gastroenterol. Nutr. 2015, 61, 30-40. [PubMed]

12. Sokol, H.; Pigneur, B.; Watterlot, L.; Lakhdari, O.; Bermúdez-Humarán, L.G.; Gratadoux, J.-J.; Blugeon, S.; Bridonneau, C.; Furet, J.-P.; Corthier, G.; et al. Faecalibacterium prausnitzii is an anti-inflammatory commensal bacterium identified by gut microbiota analysis of Crohn disease patients. Proc. Natl. Acad. Sci. USA 2008, 105, 16731-16736. [CrossRef] [PubMed]

13. Bäckhed, F.; Ding, H.; Wang, T.; Hooper, L.V.; Koh, G.Y.; Nagy, A.; Semenkovich, C.F.; Gordon, J.I. The gut microbiota as an environmental factor that regulates fat storage. Proc. Natl. Acad. Sci. USA 2004, 101, 15718-15723. [CrossRef] [PubMed]

14. Zhao, L. The gut microbiota and obesity: From correlation to causality. Nat. Rev. Microbiol. 2013, 11, 639-647. [CrossRef] [PubMed]

15. Rajilić-Stojanović, M.; de Vos, W.M. The first 1000 cultured species of the human gastrointestinal microbiota. FEMS Microbiol. Rev. 2014, 38, 996-1047. [CrossRef] [PubMed]

16. Qin, J.; Li, R.; Raes, J.; Arumugam, M.; Burgdorf, K.S.; Manichanh, C.; Nielsen, T.; Pons, N.; Levenez, F.; Yamada, T.; et al. A human gut microbial gene catalogue established by metagenomic sequencing. Nature 2010, 464, 59-65. [CrossRef] [PubMed]

17. Louis, P.; Scott, K.P.; Duncan, S.H.; Flint, H.J. Understanding the effects of diet on bacterial metabolism in the large intestine. J. Appl. Microbiol. 2007, 102, 1197-1208. [CrossRef] [PubMed]

18. Macfarlane, G.T.; Macfarlane, S. Bacteria, colonic fermentation, and gastrointestinal health. J. AOAC Int. 2012, 95, 50-60. [CrossRef] [PubMed]

19. Kolida, S.; Gibson, G.R. Synbiotics in health and disease. Annu. Rev. Food Sci. Technol. 2011, 2, $373-393$. [CrossRef] [PubMed]

20. Cani, P.D.; Neyrinck, A.M.; Fava, F.; Knauf, C.; Burcelin, R.G.; Tuohy, K.M.; Gibson, G.R.; Delzenne, N.M. Selective increases of bifidobacteria in gut microflora improve high-fat-diet-induced diabetes in mice through a mechanism associated with endotoxaemia. Diabetologia 2007, 50, 2374-2383. [CrossRef] [PubMed]

21. Cani, P.D.; Possemiers, S.; Van de Wiele, T.; Guiot, Y.; Everard, A.; Rottier, O.; Geurts, L.; Naslain, D.; Neyrinck, A.; Lambert, D.M.; et al. Changes in gut microbiota control inflammation in obese mice through a mechanism involving GLP-2-driven improvement of gut permeability. Gut 2009, 58, 1091-1103. [CrossRef] [PubMed] 
22. Fukuda, S.; Toh, H.; Hase, K.; Oshima, K.; Nakanishi, Y.; Yoshimura, K.; Tobe, T.; Clarke, J.M.; Topping, D.L.; Suzuki, T.; et al. Bifidobacteria can protect from enteropathogenic infection through production of acetate. Nature 2011, 469, 543-547. [CrossRef] [PubMed]

23. Nieuwdorp, M.; Gilijamse, P.W.; Pai, N.; Kaplan, L.M. Role of the Microbiome in Energy Regulation and Metabolism. Gastroenterology 2014, 146, 1525-1533. [CrossRef] [PubMed]

24. Tremaroli, V.; Bäckhed, F. Functional interactions between the gut microbiota and host metabolism. Nature 2012, 489, 242-249. [CrossRef] [PubMed]

25. Jernberg, C.; Löfmark, S.; Edlund, C.; Jansson, J.K. Long-term impacts of antibiotic exposure on the human intestinal microbiota. Microbiol. Read. Engl. 2010, 156, 3216-3223. [CrossRef] [PubMed]

26. Newton, D.F.; Macfarlane, S.; Macfarlane, G.T. Effects of Antibiotics on Bacterial Species Composition and Metabolic Activities in Chemostats Containing Defined Populations of Human Gut Microorganisms. Antimicrob. Agents Chemother. 2013, 57, 2016-2025. [CrossRef] [PubMed]

27. Cani, P.D.; Joly, E.; Horsmans, Y.; Delzenne, N.M. Oligofructose promotes satiety in healthy human: A pilot study. Eur. J. Clin. Nutr. 2006, 60, 567-572. [CrossRef] [PubMed]

28. Joly, C.; Gay-Quéheillard, J.; Léké, A.; Chardon, K.; Delanaud, S.; Bach, V.; Khorsi-Cauet, H. Impact of chronic exposure to low doses of chlorpyrifos on the intestinal microbiota in the Simulator of the Human Intestinal Microbial Ecosystem $\left(\mathrm{SHIME}^{\circledR}\right.$ ) and in the rat. Environ. Sci. Pollut. Res. 2013, 20, 2726-2734. [CrossRef] [PubMed]

29. Zhao, Y.; Zhang, Y.; Wang, G.; Han, R.; Xie, X. Effects of chlorpyrifos on the gut microbiome and urine metabolome in mouse (Mus musculus). Chemosphere 2016, 153, 287-293. [CrossRef] [PubMed]

30. Tirelli, V.; Catone, T.; Turco, L.; Di Consiglio, E.; Testai, E.; De Angelis, I. Effects of the pesticide clorpyrifos on an in vitro model of intestinal barrier. Toxicol. In Vitro 2007, 21, 308-313. [CrossRef] [PubMed]

31. De Wiele, T.V.; Boon, N.; Possemiers, S.; Jacobs, H.; Verstraete, W. Prebiotic effects of chicory inulin in the simulator of the human intestinal microbial ecosystem. FEMS Microbiol. Ecol. 2004, 51, 143-153. [CrossRef] [PubMed]

32. Marzorati, M.; Vilchez-Vargas, R.; Bussche, J.V.; Truchado, P.; Jauregui, R.; El Hage, R.A.; Pieper, D.H.; Vanhaecke, L.; Van de Wiele, T. High-fiber and high-protein diets shape different gut microbial communities, which ecologically behave similarly under stress conditions, as shown in a gastrointestinal simulator. Mol. Nutr. Food Res. 2016. [CrossRef] [PubMed]

33. Sivieri, K.; Morales, M.L.V.; Saad, S.M.I.; Adorno, M.A.T.; Sakamoto, I.K.; Rossi, E.A. Prebiotic effect of fructooligosaccharide in the simulator of the human intestinal microbial ecosystem (SHIME ${ }^{\circledR}$ model). J. Med. Food 2014, 17, 894-901. [CrossRef] [PubMed]

34. Selak, M.; Rivière, A.; Moens, F.; Van den Abbeele, P.; Geirnaert, A.; Rogelj, I.; Leroy, F.; De Vuyst, L. Inulin-type fructan fermentation by bifidobacteria depends on the strain rather than the species and region in the human intestine. Appl. Microbiol. Biotechnol. 2016, 100, 4097-4107. [CrossRef] [PubMed]

35. Vanhaecke, L.; Grootaert, C.; Verstraete, W.; Van de Wiele, T. Chemopreventive effects from prebiotic inulin towards microbial 2-amino-1-methyl-6-phenylimidazo[4,5-b]pyridine bioactivation. J. Appl. Microbiol. 2009, 106, 474-485. [CrossRef] [PubMed]

36. Molly, K.; Vande Woestyne, M.; Verstraete, W. Development of a 5-step multi-chamber reactor as a simulation of the human intestinal microbial ecosystem. Appl. Microbiol. Biotechnol. 1993, 39, 254-258. [CrossRef] [PubMed]

37. De Boever, P.; Deplancke, B.; Verstraete, W. Fermentation by gut microbiota cultured in a simulator of the human intestinal microbial ecosystem is improved by supplementing a soygerm powder. J. Nutr. 2000, 130, 2599-2606. [PubMed]

38. Possemiers, S.; Verthé, K.; Uyttendaele, S.; Verstraete, W. PCR-DGGE-based quantification of stability of the microbial community in a simulator of the human intestinal microbial ecosystem. FEMS Microbiol. Ecol. 2004, 49, 495-507. [CrossRef] [PubMed]

39. Djouzi, Z.; Andrieux, C.; Degivry, M.C.; Bouley, C.; Szylit, O. The association of yogurt starters with Lactobacillus casei DN 114.001 in fermented milk alters the composition and metabolism of intestinal microflora in germ-free rats and in human flora-associated rats. J. Nutr. 1997, 127, 2260-2266. [PubMed]

40. Mayeur, C.; Gratadoux, J.-J.; Bridonneau, C.; Chegdani, F.; Larroque, B.; Kapel, N.; Corcos, O.; Thomas, M.; Joly, F. Faecal D/L lactate ratio is a metabolic signature of microbiota imbalance in patients with short bowel syndrome. PLoS ONE 2013, 8, e54335. [CrossRef] [PubMed] 
41. Godon, J.J.; Zumstein, E.; Dabert, P.; Habouzit, F.; Moletta, R. Molecular microbial diversity of an anaerobic digestor as determined by small-subunit rDNA sequence analysis. Appl. Environ. Microbiol. 1997, 63, 2802-2813. [PubMed]

42. Gérard, P.; Béguet, F.; Lepercq, P.; Rigottier-Gois, L.; Rochet, V.; Andrieux, C.; Juste, C. Gnotobiotic rats harboring human intestinal microbiota as a model for studying cholesterol-to-coprostanol conversion. FEMS Microbiol. Ecol. 2004, 47, 337-343. [CrossRef]

43. De Boever, P.; Wouters, R.; Vermeirssen, V.; Boon, N.; Verstraete, W. Development of a six-stage culture system for simulating the gastrointestinal microbiota of weaned infants. Microb. Ecol. Health Dis. 2001, 13, 111-123. [CrossRef]

44. Van den Abbeele, P.; Grootaert, C.; Possemiers, S.; Verstraete, W.; Verbeken, K.; Van de Wiele, T. In vitro model to study the modulation of the mucin-adhered bacterial community. Appl. Microbiol. Biotechnol. 2009, 83, 349-359. [CrossRef] [PubMed]

45. Van den Abbeele, P.; Grootaert, C.; Marzorati, M.; Possemiers, S.; Verstraete, W.; Gérard, P.; Rabot, S.; Bruneau, A.; El Aidy, S.; Derrien, M.; et al. Microbial community development in a dynamic gut model is reproducible, colon region specific, and selective for Bacteroidetes and Clostridium cluster IX. Appl. Environ. Microbiol. 2010, 76, 5237-5246. [CrossRef] [PubMed]

46. Suau, A.; Bonnet, R.; Sutren, M.; Godon, J.J.; Gibson, G.R.; Collins, M.D.; Doré, J. Direct analysis of genes encoding 16S rRNA from complex communities reveals many novel molecular species within the human gut. Appl. Environ. Microbiol. 1999, 65, 4799-4807. [PubMed]

47. Harishankar, M.K.; Sasikala, C.; Ramya, M. Efficiency of the intestinal bacteria in the degradation of the toxic pesticide, chlorpyrifos. 3 Biotech 2013, 3, 137-142. [CrossRef]

48. Cho, K.M.; Math, R.K.; Islam, S.M.A.; Lim, W.J.; Hong, S.Y.; Kim, J.M.; Yun, M.G.; Cho, J.J.; Yun, H.D. Biodegradation of chlorpyrifos by lactic acid bacteria during kimchi fermentation. J. Agric. Food Chem. 2009, 57, 1882-1889. [CrossRef] [PubMed]

49. Singh, B.K.; Walker, A.; Morgan, J.A.W.; Wright, D.J. Effects of Soil pH on the Biodegradation of Chlorpyrifos and Isolation of a Chlorpyrifos-Degrading Bacterium. Appl. Environ. Microbiol. 2003, 69, 5198-5206. [CrossRef] [PubMed]

50. Singh, P.B.; Sharma, S.; Saini, H.S.; Chadha, B.S. Biosurfactant production by Pseudomonas sp. and its role in aqueous phase partitioning and biodegradation of chlorpyrifos. Lett. Appl. Microbiol. 2009, 49, 378-383. [CrossRef] [PubMed]

51. Duncan, S.H.; Louis, P.; Thomson, J.M.; Flint, H.J. The role of $\mathrm{pH}$ in determining the species composition of the human colonic microbiota. Environ. Microbiol. 2009, 11, 2112-2122. [CrossRef] [PubMed]

52. Collins, M.D.; Lawson, P.A.; Willems, A.; Cordoba, J.J.; Fernandez-Garayzabal, J.; Garcia, P.; Cai, J.; Hippe, H.; Farrow, J.A. The phylogeny of the genus Clostridium: Proposal of five new genera and eleven new species combinations. Int. J. Syst. Bacteriol. 1994, 44, 812-826. [CrossRef] [PubMed]

53. Byrne, C.S.; Chambers, E.S.; Morrison, D.J.; Frost, G. The role of short chain fatty acids in appetite regulation and energy homeostasis. Int. J. Obes. 2015, 39, 1331-1338. [CrossRef] [PubMed]

54. Belenguer, A.; Duncan, S.H.; Holtrop, G.; Anderson, S.E.; Lobley, G.E.; Flint, H.J. Impact of pH on lactate formation and utilization by human fecal microbial communities. Appl. Environ. Microbiol. 2007, 73, 6526-6533. [CrossRef] [PubMed]

55. Jørgensen, V.L.; Reiter, N.; Perner, A. Luminal concentrations of L- and D-lactate in the rectum may relate to severity of disease and outcome in septic patients. Crit. Care 2006, 10. [CrossRef] [PubMed]

56. Uribarri, J.; Oh, M.S.; Carroll, H.J. D-lactic acidosis: A review of clinical presentation, biochemical features, and pathophysiologic mechanisms. Medicine 1998, 77, 73-82. [CrossRef] [PubMed]

57. Belenguer, A.; Holtrop, G.; Duncan, S.H.; Anderson, S.E.; Calder, A.G.; Flint, H.J.; Lobley, G.E. Rates of production and utilization of lactate by microbial communities from the human colon. FEMS Microbiol. Ecol. 2011, 77, 107-119. [CrossRef] [PubMed]

58. Duncan, S.H.; Louis, P.; Flint, H.J. Lactate-utilizing bacteria, isolated from human feces, that produce butyrate as a major fermentation product. Appl. Environ. Microbiol. 2004, 70, 5810-5817. [CrossRef] [PubMed] 
59. Fuentes, M.S.; Briceño, G.E.; Saez, J.M.; Benimeli, C.S.; Diez, M.C.; Amoroso, M.J. Enhanced removal of a pesticides mixture by single cultures and consortia of free and immobilized Streptomyces strains. BioMed Res. Int. 2013, 2013. [CrossRef] [PubMed]

60. Luo, X.; Tsao, C.-Y.; Wu, H.-C.; Quan, D.N.; Payne, G.F.; Rubloff, G.W.; Bentley, W.E. Distal modulation of bacterial cell-cell signalling in a synthetic ecosystem using partitioned microfluidics. Lab Chip 2015, 15, 1842-1851. [CrossRef] [PubMed]

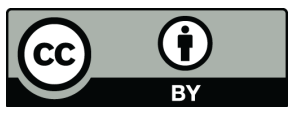

(C) 2016 by the authors; licensee MDPI, Basel, Switzerland. This article is an open access article distributed under the terms and conditions of the Creative Commons Attribution (CC-BY) license (http://creativecommons.org/licenses/by/4.0/). 